\title{
Purification and Molecular and Catalytic Properties of Bromoperoxidase from Streptomyces phaeochromogenes
}

\author{
By K ARL-HEINZ VAN PÉE AND FRANZ LINGENS* \\ Institut für Mikrobiologie der Universität Hohenheim, Garbenstrasse 30 , \\ D-7000 Stuttgart 70, FRG
}

(Received 7 February 1985; revised 9 April 1985)

A bromoperoxidase has been isolated and purified from the chloramphenicol-producing actinomycete Streptomyces phaeochromogenes. The purified enzyme was homogeneous as determined by polyacrylamide gel electrophoresis. The prosthetic group of the bromoperoxidase was ferriprotoporphyrin IX. Based on gel filtration results the molecular weight of the enzyme was $147000 \pm 3000$. Sodium dodecyl sulphate-polyacrylamide gel electrophoresis showed a single band having the mobility of a 72500 molecular weight species. Therefore, in solution at neutral $\mathrm{pH}$, the bromoperoxidase behaved as a dimer. The isoelectric point was $4 \cdot 0$. The spectral properties of the native and reduced enzyme are reported. The homogeneous enzyme also had peroxidase and catalase activity.

\section{INTRODUCTION}

Bromoperoxidases, enzymes which can use bromide ions in the presence of hydrogen peroxide and a halogen acceptor for the catalytic formation of carbon-halogen bonds, have been isolated from several marine algae (Ahern et al., 1980; Baden \& Corbett, 1980; Manthey \& Hager, 1981) and from the bacterium Pseudomonas aureofaciens (van Pée \& Lingens, 1985). The bacterial enzyme showed many differences from the algal enzymes. Surprisingly, although chlorinated metabolites are produced by marine algae (Faulkner, 1977) and bacteria (Neidleman, 1975), only brominating but not chlorinating enzymes have so far been isolated from these sources. Therefore we decided to use the chloramphenicol-producing actinomycete Streptomyces phaeochromogenes to obtain more information about bacterial halogenation.

\section{METHODS}

Reagents. Hydrogen peroxide $(30 \%, \mathrm{v} / \mathrm{v})$ was purchased from Merck and $t$-butyl hydroperoxide $(80 \%, \mathrm{v} / \mathrm{v})$ was from Fluka. Monochlorodimedone was prepared from dimedone by chlorination with sodium hypochloride (Hager et al., 1966). o-Dianisidine (3,3'-dimethoxybenzidine) was from Sigma and L-isoleucine was a gift from Degussa, Konstanz, FRG.

Organism and culture conditions. Streptomyces phaeochromogenes NRRL B-3559 was from Northern Regional Research Laboratories, Peoria, Ill., USA. The mineral salt medium described by Chatterjee et al. (1983), with glucose as the carbon source and $\mathrm{L}$-isoleucine as the nitrogen source, was used. The chloramphenicol-producing strain was grown in 2 litre Erlenmeyer flasks, containing 1 litre of medium, at $30^{\circ} \mathrm{C}$ for $96 \mathrm{~h}$ on a rotary shaker. Cells were harvested by centrifugation, yielding about $12 \mathrm{~g}$ (wet wt) $\mathrm{1}^{-1}$.

Enzyme assays. Halogenating activity and peroxidase activity were measured essentially as described for the bromoperoxidase from Pseudomonas aureofaciens (van Pée \& Lingens, 1985).

Purification of $S$. phaeochromogenes bromoperoxidase. The crude extract was prepared by suspending one part of cells (wet wt) in two parts of $50 \mathrm{~mm}$-sodium acetate buffer, pH 5.5, and disrupting with a Branson sonifier J-17 A for six $30 \mathrm{~s}$ periods. The cell debris was removed by centrifugation for $30 \mathrm{~min}$ at $22100 \mathrm{~g}$ and $4{ }^{\circ} \mathrm{C}$. Ammonium sulphate was added to the crude extract to $40 \%$ saturation, and after stirring for 20 min the precipitate was removed by centrifugation and discarded. Ammonium sulphate was added to the supernatant to $70 \%$ saturation, and stirred for $20 \mathrm{~min}$. The precipitate was removed by centrifugation, dissolved in $50 \mathrm{~mm}$-sodium acetate buffer, pH $5 \cdot 5$, and dialysed against 5 litres $50 \mathrm{~mm}$-sodium acetate buffer, $\mathrm{pH} 5 \cdot 5$, for $15 \mathrm{~h}$. After centrifugation the 
dialysed enzyme was adsorbed to a DEAE-cellulose DE52 column $(5 \times 10 \mathrm{~cm})$ equilibrated with $50 \mathrm{~mm}$-sodium acetate buffer pH $5 \cdot 5$. The sample was washed onto the column with $800 \mathrm{ml}$ of this buffer and a $500 \mathrm{ml}$ gradient of $0-0.6 \mathrm{M}-\mathrm{KCl}$ in $50 \mathrm{~mm}$-sodium acetate buffer, $\mathrm{pH} 5.5$, was applied. Then a further $250 \mathrm{ml} 0.6 \mathrm{M}-\mathrm{KCl}$ in $50 \mathrm{~mm}-$ sodium acetate buffer, pH 5.5, were passed through the column. Fractions $(3.4 \mathrm{ml})$ were assayed for protein $\left(A_{280}\right)$ and haloperoxidase activity. Those fractions (115-138), having an activity of more than $30 \%$ of the maximal activity, were pooled.

The resulting $81 \mathrm{ml}$ protein solution were dialysed against 5 litres $50 \mathrm{mM}$-Tris $/ \mathrm{HCl}, \mathrm{pH} 8 \cdot 9$, and passed onto a DEAE-cellulose DE52 column $(2.7 \times 5 \mathrm{~cm})$ equilibrated with $50 \mathrm{mM}$-Tris $/ \mathrm{HCl} \mathrm{pH} 8.9$. The sample was washed onto the column with $610 \mathrm{ml}$ of this buffer and was then eluted with a linear gradient of $500 \mathrm{ml} 0-0.5 \mathrm{M}-\mathrm{KCl}$ in $50 \mathrm{mM}$-Tris $/ \mathrm{HCl}, \mathrm{pH} 8.9$. Those fractions $(57-69)$ having an activity of more than $20 \%$ of the maximal activity were pooled and dialysed against 5 litres $5 \mathrm{~mm}$-potassium phosphate buffer, $\mathrm{pH} 7 \cdot 0$, for $15 \mathrm{~h}$. The dialysed protein solution was adsorbed to a Bio-Gel HTP hydroxylapatite column $(1.5 \times 8 \mathrm{~cm})$ equilibrated with $5 \mathrm{~mm}$-potassium phosphate buffer, $\mathrm{pH} 7 \cdot 0$. The sample was washed onto the column with $120 \mathrm{ml}$ of this buffer and eluted with $200 \mathrm{ml}$ of a linear gradient (5-50 mM) of potassium phosphate buffer $\mathrm{pH} 7 \cdot 0$. Those fractions (47-70) having more than $25 \%$ of the maximal haloperoxidase activity were pooled and concentrated to $2.3 \mathrm{ml}$ using an Amicon concentrator with a PM-30 membrane. After dialysing against 1 litre sample buffer the enzyme was further purified by preparative polyacrylamide gel electrophoresis on $7 \cdot 5 \%(\mathrm{w} / \mathrm{v})$ gels under non-dissociating conditions at pH 7.5 (Maurer, 1968).

The brownish band was cut out, immersed in 5 vols $10 \mathrm{mM}$-potassium phosphate buffer, $\mathrm{pH} 7 \cdot 0$, homogenized and stirred for $2 \mathrm{~h}$ at $4{ }^{\circ} \mathrm{C}$. After centrifugation the extraction was repeated and the acrylamide fragments were removed by centrifugation. The supernatants were concentrated to $2 \mathrm{ml}$ using an Amicon concentrator with a PM-

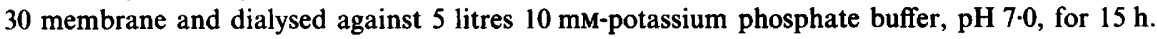

Analysis of the purified bromoperoxidase by PAGE. Analytical PAGE under non-denaturing conditions at pH 8.9 was done in a horizontal $7.5 \%(\mathrm{w} / \mathrm{v})$ polyacrylamide gel (Fehrnström \& Moberg, 1977) with an LKB 2117 Multiphor apparatus. SDS-PAGE was done by the method of Laemmli (1970).

Analytical isoelectric focusing in thin-layer plates of $5 \%(\mathrm{w} / \mathrm{v})$ polyacrylamide containing a $2 \cdot 4 \%(\mathrm{w} / \mathrm{v})$ solution of ampholines in the $\mathrm{pH}$ range 3.5-9.5 was done using an LKB Multiphor system according to the manufacturer's instructions (Winter et al., 1977). Gels were stained for protein with Coomassie Blue R250 and for peroxidase activity with $o$-dianisidine. The pI of bromoperoxidase and the molecular weight of the subunits were determined by comparing the migration of the protein with those of standard proteins.

Protein determination. Protein concentrations were measured by the method of Lowry using bovine serum albumin as a standard.

Molecular weight determination. The molecular weight of bromoperoxidase was estimated by molecular sieve chromatography with a $94 \times 3 \mathrm{~cm}$ column of Sephadex G-200, standardized with ferritin (mol. wt 440000), gamma globulin (150000), bovine serum albumin (68000), and cytochrome $c(13000)$. The column was equilibrated with $50 \mathrm{~mm}$-potassium phosphate buffer, $\mathrm{pH} 7 \cdot 0$.

Spectroscopy. Absorption spectra were recorded on a Uvicon 810 spectrophotometer (Kontron). Reduced pyridine haemochromogen was prepared by the method described by Falk (1964).

\section{RESULTS}

\section{Enzyme purification}

Previous work has shown that bacterial bromoperoxidases can not be detected in crude extracts or after ammonium sulphate fractionation (van Pée \& Lingens, 1984, 1985). They only can be detected after removal of interfering enzymes. In the case of bromoperoxidase from Sireptomyces phaeochromogenes this was achieved by the use of a DEAE-cellulose DE52 ionexchange column with sodium acetate buffer, $\mathrm{pH} 5 \cdot 5$. The results of the purification procedure are summarized in Table 1. The purified enzyme gave a single band on PAGE under nondenaturing $\left(R_{F} 0.42\right)$ and denaturing conditions (Fig. 1), when the gels were loaded with $20 \mu \mathrm{g}$ protein. The comparison with standard proteins yielded a molecular weight of 72500 for the subunits (Fig. $1 b$ ). In isoelectric focusing experiments the enzyme exhibited a single band when $20 \mu \mathrm{g}$ protein was applied to the gel. The isoelectric point was estimated to be $4 \cdot 0$.

\section{Spectral properties}

The visible absorption spectra of the native and reduced bromoperoxidase are given in Fig. 2. The native bromoperoxidase spectrum had maxima at 404, 496 and $634 \mathrm{~nm}$ with millimolar extinction coefficients $\left(\varepsilon_{\mathrm{mM}}\right)$ of $132.4,18.3$ and 11.0 , respectively. The dithionite-reduced bromoperoxidase had a Soret band at $438 \mathrm{~nm}$ with a $\varepsilon_{\mathrm{mM}}$ of $85 \cdot 2$. The visible absorption 
(a)

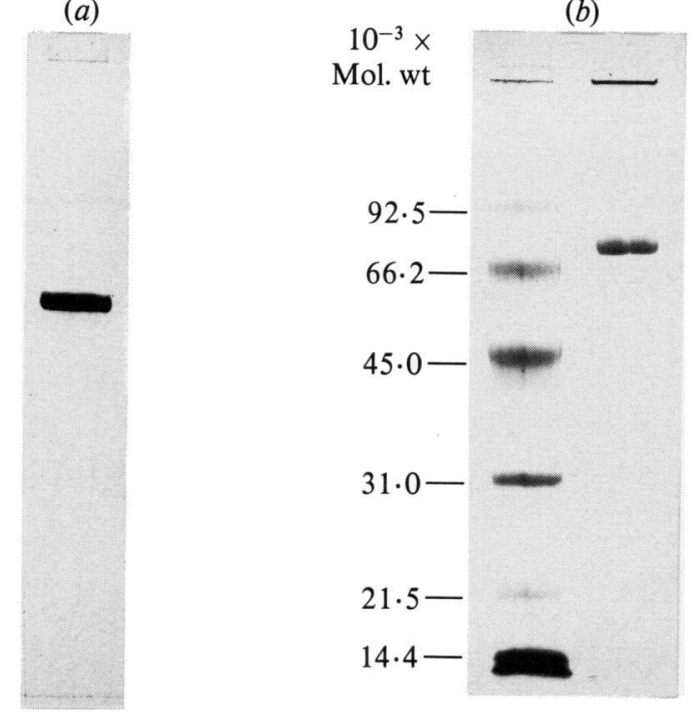

Fig. 1. SDS-PAGE of bromoperoxidase from Streptomyces phaeochromogenes under non-denaturing (a) and denaturing $(b)$ conditions. Each gel contained $20 \mu \mathrm{g}$ protein and was stained with Coomassie Blue R250. The standard proteins in the left-hand lane of $(b)$ were (molecular weights in parentheses): phosphorylase B (92500), bovine serum albumin (66200), ovalbumin (45000), carbonic anhydrase $(31000)$, soybean trypsin inhibitor (21500) and lysozyme (14400).

Table 1. Summary of the purification of bromoperoxidase from Streptomyces phaeochromogenes The enzyme was purified from $275 \mathrm{~g}$ bacteria; - , could not be determined.

$\begin{array}{lcccccc}\begin{array}{c}\text { Purification } \\ \text { step }\end{array} & \begin{array}{c}\text { Total vol. } \\ (\mathrm{ml})\end{array} & \begin{array}{c}\text { Total } \\ \text { protein } \\ \text { (mg) }\end{array} & \begin{array}{c}\text { Total } \\ \text { activity } \\ \text { (units) }\end{array} & \begin{array}{c}\text { Specific } \\ \text { activity } \\ \text { [units (mg } \\ \text { protein) }\end{array} & \begin{array}{c}\text { Percentage } \\ \text { yield }\end{array} & \begin{array}{c}\text { Purification } \\ \text { (fold) }\end{array} \\ \begin{array}{l}\text { Crude supernatant } \\ \begin{array}{l}\text { 40-70\% }\left(\mathrm{NH}_{4}\right)_{2} \mathrm{SO}_{4} \\ \text { precipitation }\end{array}\end{array} & 1155 & 1155 & - & - & - & - \\ \begin{array}{l}\text { DEAE-cellulose DE52 } \\ \text { ion-exchange } \\ \text { chromatography: }\end{array} & 100 & 650 & - & - & - & - \\ \begin{array}{l}\text { pH 5.5 } \\ \text { pH 8.9 }\end{array} & 81 & 113 & 6.8 & 0.06 & 100 & 1.0 \\ \begin{array}{l}\text { Bio-Gel HTP hydroxyl- } \\ \text { apatite }\end{array} & 47 & 32.9 & 3.6 & 0.11 & 52.9 & 1.8 \\ \text { Preparative PAGE } & 2.3 & 7.8 & 2.6 & 0.34 & 38.2 & 5.7 \\ \end{array}$

spectrum of the ferrous enzyme had a peak at $557 \mathrm{~nm}$ with a shoulder at $592 \mathrm{~nm}$. The $\varepsilon_{\mathrm{mM}}$ values were 11.5 and $6 \cdot 1$, respectively. When reduced in alkaline pyridine, bromoperoxidase yielded a haemochromogen whose spectrum was identical with that of protohaem IX (Fig. 3). On the basis of the absorbance at $557 \mathrm{~nm}\left(\varepsilon_{\mathrm{mM}} 34.4\right.$; Falk, 1964), haem content of 0.91 molecules per dimeric molecule of bromoperoxidase was calculated. The purified enzyme had an $A_{404} / A_{274}$ ratio of 0.4 which is consistent with the low haem content.

\section{Reactions catalysed by bromoperoxidase}

Bromoperoxidase in the presence of hydrogen peroxide and bromide catalysed the bromination of monochlorodimedone, but not the chlorination or fluorination of this organic substrate. When hydrogen peroxide was substituted by $t$-butyl hydroperoxide, no brominating 


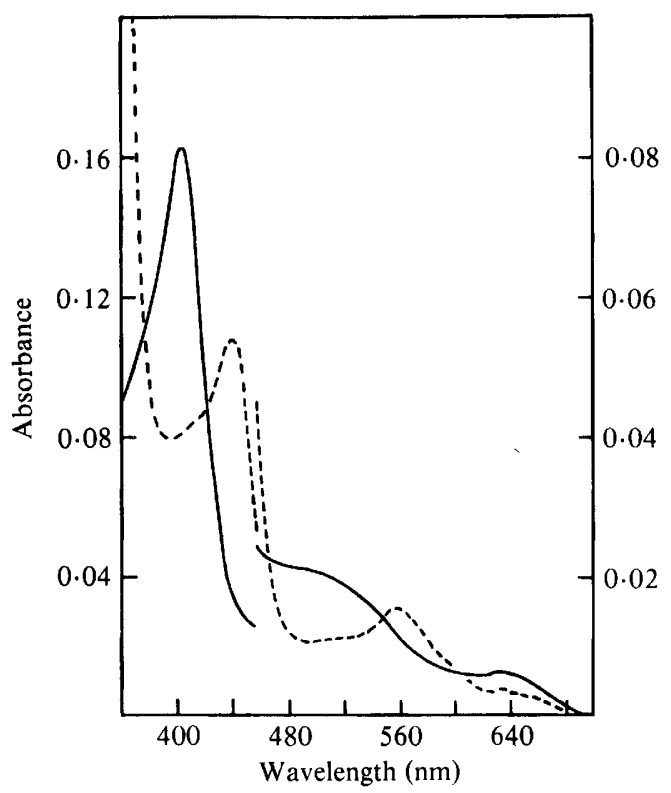

Fig. 2

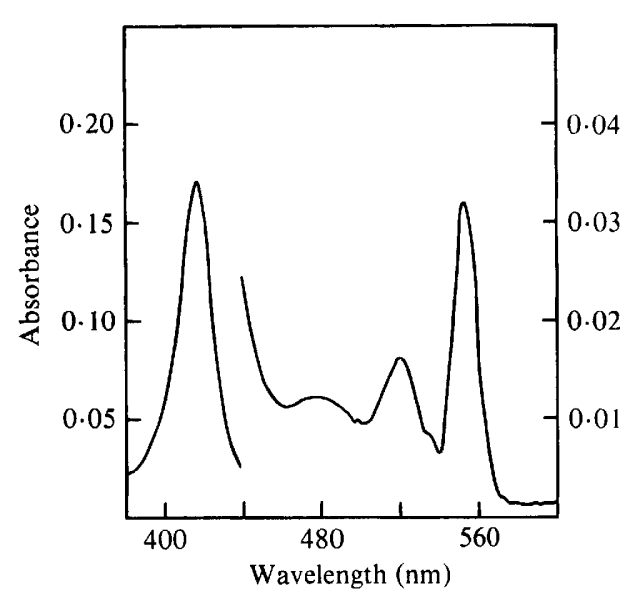

Fig. 3

Fig. 2. Absorption spectra of native and reduced bromoperoxidase. The spectra of native ( - ) and reduced (-- ) bromoperoxidase $(1 \cdot 3 \mu \mathrm{M})$ were recorded in $25 \mathrm{mM}$-potassium phosphate buffer, $\mathrm{pH} 7 \cdot 0$.

Fig. 3. Pyridine haemochromogen spectrum. Bromoperoxidase was present at $1 \cdot 2 \mu \mathrm{M}$ final concentration. The method of haemochromogen preparation is described in Methods.

activity could be detected. The enzyme activity, however, was not inhibited by $t$-butyl hydroperoxide. Bromoperoxidase in the absence and presence of bromide was able to catalyse the oxidation of $o$-dianisidine, pyrogallol and $o$-phenylendiamine. Catalase activity could also be measured under the same conditions as peroxidase and haloperoxidase activity. With $t$-butyl hydroperoxide instead of hydrogen peroxide neither peroxidase nor catalase activity could be detected.

\section{pH optima of the different catalytic activities of bromoperoxidase}

The $\mathrm{pH}$ optima of the three catalytic activities of this bromoperoxidase were slightly different (Fig. 4). The optima for the brominating and peroxidase activities were at $\mathrm{pH} 5 \cdot 0$, whereas the optimum for the catalase activity was at $\mathrm{pH} 7 \cdot 0$.

\section{DISCUSSION}

When crude extracts from Streptomyces phaeochromogenes were incubated in the presence of monochlorodimedone, hydrogen peroxide and bromide, no enzyme reaction could be detected. However, when the supernatant solution was incubated in the presence of $o$-dianisidine and hydrogen peroxide, oxidation of the substrate was evident. The same phenomenon was observed with extracts from the bacterium Pseudomonas aureofaciens (van Pée \& Lingens, 1985) and from the marine alga Penicillus lamourouxii (Baden \& Corbett, 1980). In the latter case, however, bromoperoxidase activity could already be detected after precipitation and concentration by ammonium sulphate fractionation. With extracts from $S$. phaeochromogenes ammonium sulphate fractionation and ion-exchange chromatography had to be done before brominating activity was detectable. In the case of bromoperoxidase from Ps. aureofaciens even a second ionexchange chromatography step was necessary before brominating activity could be measured. This demonstrates one of the problems with the isolation of bacterial haloperoxidases, which is probably due to the fact that crude extracts contain a very efficient catalase. This catalase 


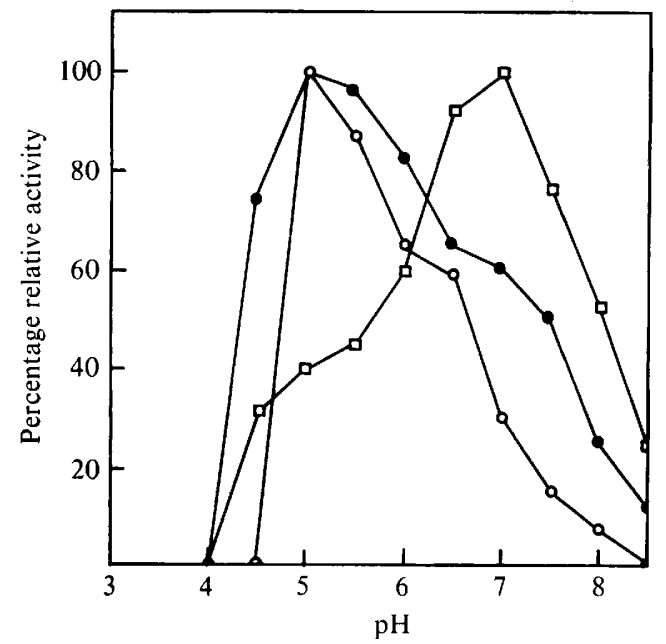

Fig. 4. Brominating, peroxidase and catalase activities of bromoperoxidase as a function of $\mathrm{pH}$. The brominating activity was measured by the monochlorodimedone assay $(O)$. Peroxidase activity was determined by the $O$-dianisidine assay $(O)$. Catalase activity was measured by following the decomposition of hydrogen peroxide at $240 \mathrm{~nm}(\square)$. Buffering was achieved with 0.1 M-potassium phosphate buffer. $100 \%$ activity corresponded to the maximal activity.

Table 2. Comparison of bromoperoxidase from Streptomyces phaeochromogenes with bromoperoxidase from Pseudomonas aureofaciens, with an algal bromoperoxidase from Penicillus capitatus, and with chloroperoxidase from Caldariomyces fumago

$\begin{array}{lcccc} & \begin{array}{c}\text { Streptomyces } \\ \text { phaeochromogenes }\end{array} & \begin{array}{c}\text { Pseudomonas } \\ \text { aureofaciens }\end{array} & \begin{array}{c}\text { Penicillus } \\ \text { capitatus* }\end{array} & \begin{array}{c}\text { Caldariomyces } \\ \text { fumago }\end{array} \\ 10^{-3} \times \text { Mol. wt } & 144-150 & 155-158 & 97 & 42 \\ \text { Subunits } & 2 & 2 & 2 & 1 \\ \text { Spectrum peak wave- } & 404 & 405 & 413 & 403 \\ \text { length (nm) } & 496 & 500 & 495 & 515 \\ & & 540 \ddagger & 545 \ddagger & 542 \\ \text { Haem-type } & 634 & 631 & 635 & 650 \\ \text { Chlorination } & \mathrm{IX} & \mathrm{IX} & \mathrm{IX} & \mathrm{IX} \\ \text { Bromination } & - & - & - & + \\ \text { Oxidation of } o \text {-dianisidine } & + & + & + & + \\ \text { Catalase activity } & + & + & + & + \\ \text { pH optimum (bromination) } & + & + & 4 \cdot 0 \dagger & 2 \cdot 75 \\ & \text { * Data from Manthey \& Hager (1981). } & \\ & \text { † Data from Baden \& Corbett (1980). } & \\ & \text { † Shoulder of peak. } & \end{array}$

competes with bromoperoxidase for hydrogen peroxide. Therefore bromoperoxidase activity can only be detected after removal of the catalase. The molecular weight of the bromoperoxidase from $S$. phaeochromogenes is very similar to that of the other bacterial bromoperoxidases already described (Table 2), but quite different from those of the eukaryotic bromoperoxidases from marine algae (Baden \& Corbett, 1980; Manthey \& Hager, 1981) and that of the chloroperoxidase from the fungus Caldariomyces fumago (Morris \& Hager, 1966). Both bacterial bromoperoxidases form a dimer, consisting of two identical subunits, a characteristic they share with only one of the described algal bromoperoxidases. The spectral properties of the bacterial bromoperoxidases parallel those of the algal bromoperoxidases and chloroperoxidase. The prosthetic group of all these enzymes is protoporphyrin IX. Like the eukaryotic haloperoxidases the two bacterial bromoperoxidases also have catalase and peroxidase activity, but their brominating activity is rather low and the two other activities are very high. Like the algal 
bromoperoxidases, those from $S$. phaeochromogenes and Ps. aureofaciens exhibit no chlorinating activity. This is very surprising, especially as $S$. phaeochromogenes produces chloramphenicol and Ps. aureofaciens produces the antifungal antibiotic pyrrolnitrin, both chlorinated metabolites. Geigert et al. (1984) postulated a bromonium ion-induced chlorination for the synthesis of chlorinated metabolites in marine algae. Whether this also holds for the formation of chlorinated metabolites from bacteria is not yet known, but will be the subject of further investigations.

We thank the Fonds der Chemischen Industrie for financial support.

Dedicated to Professor Wolfram Zillig on the occasion of his 60th birthday.

\section{REFERENCES}

Ahern, T. J., Allan, G. G. \& Medcalf, D. G. (1980). New bromoperoxidases of marine origin: partial purification and characterisation. Biochimica et biophysica acta 616, 329-339.

Baden, D. G. \& CorbetT, M. D. (1980). Bromoperoxidases from Penicillus capitatus, Penicillus lamourouxii and Rhipocephalus phoenix. Biochemical Journal 187, 205-211.

Chatterjee, S., Vining, L. C. \& Westlake, D. W. S. (1983). Nutritional requirements for chloramphenicol biosynthesis in Streptomyces venezuelae. Canadian Journal of Microbiology 29, 247-253.

FALK, J. E. (1964). Porphyrines and Metalloporphyrines: Their General Physical and Coordination Chemistry, and Laboratory Methods. B.B.A. Library, vol. 2. Amsterdam, London \& New York: Elsevier.

FAULKNER, D. J. (1977). Interesting aspects of marine natural products chemistry. Tetrahedron 33, 14211443.

FeHRNSTRÖM, H. \& MOBERG, U. (1977). SDS and conventional polyacrylamide gel electrophoresis with LKB 2117 Multiphor. LKB Application Note 306.

Geigert, J., Neidlman, S. L., De Witt, S. K. \& Dalietos, D. J. (1984), Halonium ion-induced biosynthesis of chlorinated marine metabolites. Phytochemistry 23, 287-290.

Hager, L. P., Morris, D. R., Brown, F. S. \&
Eberwein, H. (1966). Chloroperoxidase II. Utilisation of halogen anions. Journal of Biological Chemistry 241, 1769-1777.

LAEMMLI, U. K. (1970). Cleavage of structural proteins during the assembly of the head of bacteriophage T4. Nature, London 227, 680-685.

Manthey, J. A. \& Hager, L. P. (1981). Purification and properties of bromoperoxidase from Penicillus capitatus. Journal of Biological Chemistry 256, 1123211238.

MAURER, H. R. (1968). Disk-Elektrophorese: Theorie und Praxis der diskontinuierlichen Polyacrylamidgel-Elektrophorese. Berlin: Walter de Gruyter.

MORRIS, D. R. \& HAGER, L. P. (1966). Chloroperoxidase. I. Isolation properties of the crystalline glycoprotein. Journal of Biological Chemistry 241, 17631768.

NeIdleman, S. L. (1975). Microbial halogenation. CRC Critical Reviews of Microbiology 5, 333-358.

VAN PÉE, K.-H. \& Lingens, F. (1984). Detection of a bromoperoxidase in Streptomyces phaeochromogenes. FEBS Letters 173, 5-8.

vaN PÉE, K.-H. \& Lingens, F. (1985). Purification of bromoperoxidase from Pseudomonas aureofaciens. Journal of Bacteriology 161, 1171-1175.

WinTER, A., EK, K. \& ANDERSSON, U.-B. (1977). Analytical electrofocusing in thin layers of polyacrylamide gels. LKB Application Note 250. 